\title{
PROSES SUKSESI DAN PEMAHAMAN AKUNTANSI PADA KEBERHASILAN BISNIS KELUARGA
}

\author{
Fella \\ Universitas Kristen Satya Wacana, Salatiga \\ 232016021@student.uksw.edu \\ Ika Kristianti \\ Universitas Kristen Satya Wacana, Salatiga \\ ika.kristianti@uksw.edu
}

\begin{abstract}
Abstrak: Proses Suksesi dan Pemahaman Akuntansi Pada Keberhasilan Bisnis
Keluarga. Penelitian ini dilakukan bertujuan untuk mengetahui hubungan antara proses suksesi dan pemahaman akuntansi terhadap keberhasilan bisnis keluarga. Subjek penelitian ini adalah pemilik bisnis keluarga di Salatiga dan Semarang. Penelitian ini menggunakan pendekatan kuantitatif dengan metode pengujian regresi linier. Sampel dari penelitian ini sebanyak 158 pengelola dan pemilik bisnis keluarga di Semarang dan Salatiga. Sebaran perolehan data diperoleh 78 dari responden Semarang, sedangkan 80 berasal dari Salatiga. Data diperoleh dari penyebaran kuesioner melalui google form dan penyebaran kuesioner langsung pada daerah penelitian. Berdasarkan hasil uji t, dapat disimpulkan bahwa proses suksesi berpengaruh terhadap keberhasilan bisnis keluarga dan pemahaman akuntansi berpengaruh terhadap keberhasilan bisnis keluarga.
\end{abstract}

Kata kunci: Proses Suksesi, Pemahaman Akuntansi, Keberhasilan Bisnis Keluarga

\begin{abstract}
Proses Suksesi dan Pemahaman Akuntansi Pada Keberhasilan Bisnis
Keluarga.This study is conducted to determine the relationship between the succession process and accounting understanding on the success of family business. The subjects of this study are family business owners in Salatiga and Semarang. This research uses quantitative approach with linear regression testing method. The samples are 158 managers and owners of family business; 78 from Semarang and 80 from Salatiga. The researcher obtains data by distributing questionnaires both through Google Form and directly to the subjects in the studied area. Based on the results of the T-test it can be concluded that both the succession process and the understanding of accounting influence the success of family business.
\end{abstract}

Keywords: Succession Process, Accounting Understanding, Success of Family Business

\section{PENDAHULUAN}

Proses suksesi sangat dibutuhkan dalam menjalankan sebuah bisnis, biasanya calon suksesor dipersiapkan sejak dini baik pendidikan secara formal dan informal. Proses pembentukan karakter calon suksesor peran keluarga sangat dibutuhkan. Kepemimpinan dalam menjalankan bisnis keluarga juga sangat diperhatikan dalam proses suksesi, karena dengan kepemimpinan yang baik dapat membuat bisnis yang dijalankan semakin berkembang dan sukses (Halim, 2013; Wahjono, 2011, 2009; Wiratna \& Tambunan, 2017). Menurut Wijaya dan 


\section{Nominal: Barometer Riset Akuntansi dan Manajemen}

P-ISSN: 2303-2065 E-ISSN: 2502-5430

Volume 9 No 1 (2019)

Mustamu (2014) proses suksesi membutuhkan waktu yang lama, karena dalam pemilihan suksesor yang dapat menentukan keberhasilan sebuah bisnis. Pemilihan suksesor yang tepat akan membuat sebuah bisnis terus berkembang (going concern), walaupun pendiri sudah tidak ikut membantu mengembangkan bisnis tersebut. Stefanny dan Indriyani (2013) menjelaskan bahwa sebuah bisnis yang sukses merupakan bisnis yang dapat berkembang dari generasi ke generasi. Terdapat dua jenis bisnis keluarga yaitu Family Owned Enterprise (FOE) dan Family Business Enterprise (FBE). FOE merupakan bisnis yang dimiliki keluarga, namun dikelola dari luar lingkungan keluarga seperti pengelolaan oleh eksekutif professional. FBE adalah bisnis yang dimiliki serta dikelola oleh anggota keluarga itu sendiri.

$$
\text { Kamener dan Putri (2017) }
$$
menjelaskan bisnis keluarga yang dijalankan dan dikelola oleh anggota keluarga itu sendiri memiliki beberapa tujuan diantaranya untuk menjamin kesejahteraan hidup anggota keluarganya. Menurut Wijaya dan Mustamu (2014) bisnis keluarga yang mampu bertahan dan berkembang sampai saat ini, pasti memiliki rencana yang matang dan keinginan untuk lebih berkembang di masa depan. Di sisi lain, beberapa penelitian menyatakan bahwa keberhasilan bisnis keluarga akan mulai menurun pada generasi kedua, dan hanya sekitar $10 \%$ yang bertahan pada generasi ketiga (Aronoff, 2001; Stalk \& Foley, 2012; Ward, 2004). Isu kelanggengan usaha masih menjadi salah satu isu strategis bagi setiap organisasi bisnis (Tjiptono, 2013). Kelanggengan usaha seringkali mengacu pada durasi eksistensi yang panjang, keberlanjutan atas usaha yang telah dibangun, serta proses menurunkan usaha kepada generasi berikutnya. Kesuksesan sebuah bisnis tidak hanya dilihat dari modal, sumber daya yang dimiliki, dan inovasi tetapi juga melihat dari aspek lain seperti pemahaman akuntansi yang diterapkan dalam sebuah bisnis.

Standar akuntansi keuangan adalah metode yang diciptakan agar seragam dalam menyajikan informasi yang berupa laporan keuangan, sehingga dapat dibandingkan dengan mudah. Banyak bisnis keluarga yang tidak mengerti pemahaman akuntansi bahkan sering melakukan kesalahan - kesalahan yang dapat menyebabkan kebangkrutan dalam bisnis yang dikelolanya. Kesalahan yang sering dilakukan oleh bisnis keluarga yang tidak mengerti tentang pemahaman akuntansi salah satunya adalah tidak memisahkan antara uang pribadi dan uang bisnis, hal ini sebenarnya terlihat sederhana 


\section{Nominal: Barometer Riset Akuntansi dan Manajemen}

P-ISSN: 2303-2065 E-ISSN: 2502-5430

Volume 9 No 1 (2019)

namun memiliki dampak yang besar bagi bisnis tersebut (Adam 2015). Pelaporan keuangan bagi bisnis keluarga merupakan informasi akuntansi yang memiliki peran penting dalam keberhasilan sebuah bisnis. Pelaporan keuangan akan digunakan oleh sebuah bisnis untuk pengambilan keputusan. Jika seseorang tidak memahami bagaimana cara membuat laporan keuangan dengan baik, maka laporan yang akan dihasilkan tidak dapat digunakan untuk pengambilan keputusan karena hasil dari laporan keuangan bisa menyesatkan dan membuat bisnis tersebut akan bangkrut jika laporan keuangan yang menyesatkan digunakan dalam pengambilan keputusan (Devi, Herawati, \& Sulindawati, 2017).

Terdapat banyak bisnis keluarga yang tidak mampu bertahan lama, salah satunya disebabkan oleh tidak adanya perencanaan suksesi yang matang sejak dini (Lily \& Praptiningsih, 2014). Adam (2015) menjelaskan bahwa sebuah bisnis harus dapat membedakan penempatan akun debit dan kredit, hal ini dikarenakan jika bisnis tidak dapat memahami posisi akun debit kredit maka laporan yang dihasilkan tidak dapat dipakai untuk mengambil keputusan dan hal ini berpengaruh bagi keberlangsungan bisnis tersebut. Menurut Rombe et al. (2016) pemahaman akuntansi dapat membantu bisnis dalam memberikan informasi yang dibutuhkan dalam pengambilan keputusan. Jika dalam bisnis melakukan kesalahan dalam mencatat, menghitung dan melaporkan hal ini sangat berpengaruh bagi sebuah bisnis dalam membuat sebuah keputusan untuk keberlangsungan bisnisnya.

Modal yang di dapatkan dalam menjalankan sebuah bisnis sangat diperhatikan dalam pemahaman akuntansi, karena modal tidak selalu berasal dari keluarga itu sendiri melainkan bisa saja melalui hutang (Septiani \& Mustamu, 2014). Rombe et al. (2016) menjelaskan tentang adanya pemikiran mengenai bisnis keluarga yang tidak profesional dikarenakan bisnis keluarga tidak dapat memisahkan antara kepentingan pribadi dengan kepentingan bisnis, bisnis keluarga lebih mengutamakan hubungan keluarga daripada kinerja dalam bisnis keluarga dan pengendalian yang ada tidak terkontrol dengan baik. Namun pada kenyataannya, banyak dari bisnis keluarga lebih mementingkan sikap profesional dalam menjalankan bisnisnya dibandingkan dengan mementingkan sikap kekeluargaan.

Informasi tersebut menunjukkan bahwa perputaran perekonomian Indonesia terbantu dengan adanya pertumbuhan UKM yang semakin meningkat. Pertumbuhan UKM di Indonesia, tidak hanya dimonopoli oleh beberapa daerah saja, namun hampir diseluruh daerah di 


\section{Nominal: Barometer Riset Akuntansi dan Manajemen}

P-ISSN: 2303-2065 E-ISSN: 2502-5430

Volume 9 No 1 (2019)

Indonesia memiliki visi dalam pengembangan UKM masing-masing daerah. Terlihat pada gambar 1 yang menggambarkan pertumbuhan UKM di Jawa Tengah sejak tahun 2008 - 2019 sebanyak $83 \%$. Berdasarkan data diatas bahwa bisnis keluarga setiap tahunnya mengalami pertumbuhan. Menurut Aditya (2018) di Salatiga pada tahun 2017 terdapat 1.200 bisnis keluarga yang didirikan dan tahun 2018 terdapat 1.400 bisnis keluarga yang didirikan. Dinas Koperasi dan Usaha Mikro Kota Semarang (2019) menjelaskan sampai tahun 2019, di Kota Semarang telah berdiri 16.398 bisnis keluarga.UKM sering kali juga dikatakan sebagai bisnis keluarga, karena dalam mendirikan UKM terdapat peran anggota keluarga baik dalam kepemilikan maupun aktivitas bisnis.

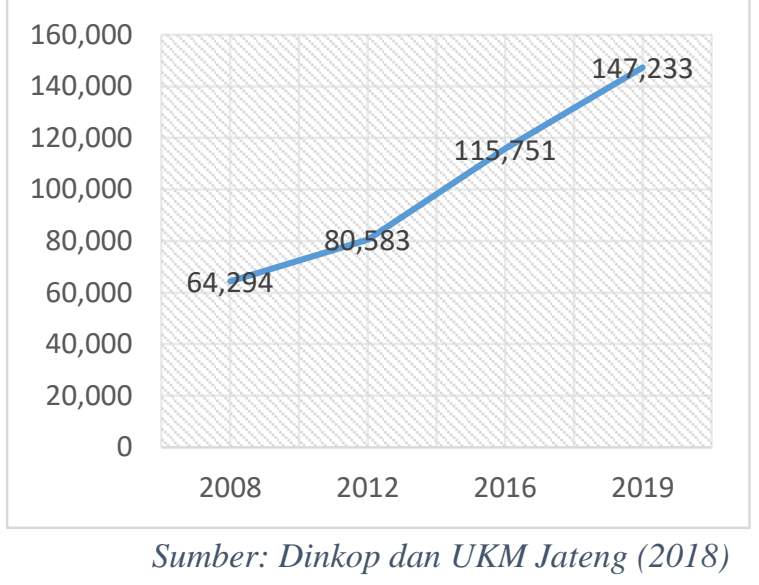

Gambar 1: Grafik Perkembangan UKM

Binaan di Jawa TengahTahun 2008 - 2019

Telah terdapat beberapa penelitian yang sebelumnya membahas mengenai topik ini, namun khusus untuk di Semarang dan Salatiga jarang ada yang meneliti.
Alasan pertama mengapa penelitian ini dilakukan di Semarang yaitu banyak bisnis keluarga yang membangun bisnis nya di Semarang, bahkan saat ini sudah berkembang sangat pesat dan mampu mendirikan perusahan besar atau membuka cabang di Indonesia serta perusahaan tersebut sudah terdaftar dalam Bursa Pasar Modal (BPM). Alasan kedua mengapa penelitian ini dilakukan di Salatiga karena dulu Salatiga dikenal sebagai kota kecil yang masih sepi, namun sekarang kota kecil itu sudah berubah. Banyak bisnis keluarga yang di dirikan di Salatiga sehingga Salatiga bisa disebut sebagai kawasan industri. Salatiga tidak mempunyai tempat wisata, hal ini yang menjadi daya tarik bagi pemilik bisnis untuk memulai bisnis nya di Salatiga karena banyak nya mahasiswa dari sabang sampai merauke yang memilih untuk sekolah bahkan kuliah di Salatiga. Salatiga juga sebagai jalur penghubung antara Semarang dan Solo. Hal ini yang membuat peneliti ingin melakukan penelitian ini di Semarang dan Salatiga.

Penelitian ini dilakukan untuk melihat proses suksesi dan pemahaman akuntansi terhadap keberhasilan bisnis keluarga. Rumusan penelitian ini adalah bagaimana pengaruh proses suksesi dan pemahaman akuntansi terhadap keberhasilan bisnis keluarga di Semarang dan Salatiga. Tujuan dari penelitian ini 


\section{Nominal: Barometer Riset Akuntansi dan Manajemen}

P-ISSN: 2303-2065 E-ISSN: 2502-5430

Volume 9 No 1 (2019)

untuk mengetahui pengaruh proses suksesi terhadap keberhasilan bisnis keluarga serta untuk mengetahui pemahaman akuntansi terhadap keberhasilan bisnis keluarga di Semarang dan Salatiga. Manfaat penelitian ini diharapkan dapat membantu pemilik bisnis keluarga dalam melakukan proses suksesi serta dapat membantu pemilik bisnis keluarga dalam pemahaman akuntansi.

\section{KAJIAN TEORI}

\section{Proses Suksesi (Bisnis Keluarga)}

Hal yang paling penting dalam sebuah bisnis keluarga adalah pergantian pemimpin (suksesi), banyak juga bisnis yang belum mampu dengan adanya pergantian kepemimpinan sehingga banyak bisnis yang berhenti sampai generasi pertama (Wahjono, 2009). Bisnis keluarga yang dijalankan dan dikelola oleh anggota keluarga itu sendiri serta memiliki beberapa tujuan diantaranya untuk menjamin kesejahteraan hidup anggota keluarganya (Kamener \& Putri, 2017). Menurut Wahjono (2011, 2009) dalam proses suksesi biasanya calon suksesor sudah dipersiapkan sejak dini mengenai pendidikannya. Calon suksesor akan diajak untuk membantu mengelola dan menjalankan bisnis nya sejak dini. Wiratna dan Tambunan(2017) menjelaskan dalam pembentukan karakter calon suksesor sangat dibutuhkan peran keluarga, salah satunya didikan orang tua dan bagaimana orang tua memberikan pemahaman mengenai bisnis. Halim (2013) mengatakan bahwa kepemimpinan dalam mengelola bisnis sangat diperhatikan, karena dengan kepemimpinan yang baik dapat membuat bisnis yang dijalankan semakin berkembang dan sukses.

Kesuksesan sebuah bisnis tidak hanya dilihat dari bagaimana kepemimpinan yang ada namun modal, sumber daya yang dimiliki, dan inovasi merupakan aspek yang diperhatikan, selain itu pemahaman akuntansi yang diterapkan dalam sebuah bisnis juga sangat diperhatikan. Terkadang banyak bisnis keluarga yang tidak mengerti pemahaman akuntansi dan melakukan kesalahan yang dapat menyebabkan bangkrutnya sebuah bisnis. Sebuah bisnis pasti terdapat resiko yang harus diambil untuk menentukan keberlangsungan bisnisnya (Wijaya \& Mustamu, 2014). Menurut Remiasa dan Wijaya (2014) suksesi merupakan proses pengalihan kekuasaan kepemimpinan dari pemilik sebelumnya ke pemilik selanjutnya. Pengalihan kepemilikan ini memiliki peluang besar untuk menciptakan suksesor yang dapat mengembangkan bisnis dengan baik dibanding pemilik sebelumnya. Proses dalam memilih suksesi terdapat beberapa tahapan yang dimulai 


\section{Nominal: Barometer Riset Akuntansi dan Manajemen}

P-ISSN: 2303-2065 E-ISSN: 2502-5430

Volume 9 No 1 (2019)

dengan pemilihan calon suksesor serta pengembangan dan pemeliharaan calon suksesor.

Menurut Susanto (2005; 2007) proses menentukan calon suksesor merupakan tahap pengembangan dan pemeliharaan suksesor. Yang dimaksud ditahap ini yaitu sebagai calon suksesor harus memiliki pendidikan serta pengetahuan yang dapat digunakan untuk mengembangkan sebuah bisnis. Calon suksesor diharapkan dapat memanfaatkan kesempatan belajar dengan baik seperti pendidikan formal, pelatihan, berbagi pengalaman dan pengetahuan tentang dunia bisnis. Cara yang paling efektif bagi calon suksesor adalah dengan melibatkan calon suksesor dalam bisnis tersebut termasuk dalam proses pengambilan keputusan maupun memanfaatkan peluang yang ada. Setelah itu dilakukan evaluasi kinerja calon suksesor dengan membandingkan harapan tim dengan kenyataan yang terjadi.

\section{Pemahaman Akuntansi}

Standar akuntansi keuangan adalah metode yang diciptakan agar seragam dalam penyajian informasi yang berupa laporan keuangan, sehingga dapat dibandingkan dengan mudah (Adam, 2015). Laporan keuangan berisi informasi sebuah bisnis yang menggambarkan kinerja bisnis tersebut setiap periode berjalan. Laporan keuangan ini biasanya dipakai

untuk pengambilan keputusan untuk berlangsungnya sebuah bisnis dan pihak pihak yang berkepentingan (Ikatan Akuntan Indonesia, 2016). Akuntansi memiliki peran bisnis dalam menjalankan sebuah bisnis, tujuan utama akuntansi yaitu untuk mencatat, melaporkan dan membuat laporan keuangan yang akan digunakan untuk pengambilan keputusan (Ikhsan dan Suprasto, 2008). Menurut Wijaya dan Mustamu (2014) kesuksesan sebuah bisnis tidak hanya dilihat dari modal, sumber daya yang dimiliki, dan inovasi tetapi juga dilihat dari aspek lain seperti pemahaman akuntansi yang diterapkan dalam sebuah bisnis. Terkadang banyak bisnis keluarga yang tidak mengerti pemahaman akuntansi dan melakukan kesalahan yang dapat menyebabkan bangkrutnya sebuah bisnis. Sebuah bisnis pasti terdapat resiko yang harus diambil untuk menentukan keberlangsungan bisnisnya. Menurut Adam (2015) persamaan dasar akuntansi (the accounting equation) yang wajib diketahui oleh pengguna informasi.

Menurut Istiqomah dan Hatammimi (2015) akuntansi sebagai proses menganalisa dan melaporkan transaksi keuangan, transaksi diartikan sebagai persetujuan antara dua pihak. Sebuah bisnis harus dapat memisahkan uang pribadi dan uang bisnis, karena jika tidak ada pemisahan dapat membuat bisnis yang 
sudah berjalan dapat menjadi bangkrut.Septiani dan Mustamu (2014) juga menjelaskan modal yang di dapat dalam menjalankan sebuah bisnis sangat diperhatikan dalam pemahaman akuntansi, karena modal tidak selalu berasal dari keluarga itu sendiri melainkan bisa saja melalui hutang.Menurut Sariningtyas dan Diah (2011) pencatatan akuntansi merupakan salah satu komponen yang harus dimiliki sebuah bisnis jika ingin mengembangkan bisnis yang sudah didirikannya, mengembangkan usahanya dapat dilakukan dengan mengajukan pinjaman kepada kreditur.

Adapun manfaat yang didapat dalam pencatatan akuntansi adalah dapat menghindari campur tangan antara uang pribadi dengan uang bisnis, karena kebanyakan bisnis keluarga tidak menerapkan pemahaman akuntansi dengan baik dan mencampurkan uang pribadi dan bisnis. Permasalahan yang terdapat diatas, maka dengan adanya pencatatan akuntansi sangat membantu sebuah bisnis agar dapat berkembang. Manfaat pencatatan akuntansi bagi kreditor adalah dengan melihat perkembangan bisnis serta mengestimasikan kinerja sebuah bisnis pada masa depan. Pemilik bisnis harus membiasakan untuk membuat dan menyajikan laporan keuangan sebagai alat untuk mengambil keputusan bagi keberlangsungan bisnis. Kemauan yang rendah dari pemilik bisnis untuk membuat pencatatan akuntansi dikarenakan pemilik bisnis belum mendapat pemahaman akuntansi yang baik dan belum mengerti pentingnya pencatatan akuntansi bagi keberlangsungan bisnis (Sariningtyas \& Diah 2011).

\section{Pengembangan Hipotesis}

Pengaruh proses suksesi terhadap keberhasilan bisnis keluarga

Menurut Remiasa dan Wijaya (2014) suksesi merupakan proses pengalihan kekuasaan kepemimpinan dari pemilik sebelumnya ke pemilik selanjutnya. Proses dalam memilih suksesi terdapat beberapa tahapan yang dimulai dengan pemilihan calon suksesor serta pengembangan dan pemeliharaan calon suksesor. Susanto (2005; 2007) menjelaskan bahwa calon suksesor harus memiliki pendidikan serta pengetahuan yang dapat digunakan untuk mengembangkan sebuah bisnis. Calon suksesor diharapkan dapat memanfaatkan kesempatan belajar dengan baik seperti pendidikan formal, pelatihan, berbagi pengalaman dan pengetahuan tentang dunia bisnis. Cara yang paling efektif bagi calon suksesor adalah dengan melibatkan calon suksesor dalam bisnis tersebut termasuk dalam proses pengambilan keputusan 
maupun memanfaatkan peluang yang ada. Menurut Kamener dan Putri; Wiratna dan Tambunan (2017) dalam hasil penelitian yang telah dilakukan, bahwa proses suksesi berpengaruh terhadap keberhasilan bisnis keluarga. Keberhasilan bisnis keluarga juga disebabkan karena adanya peran orangtua dalam perencanaan suksesi sejak dini serta adanya kepercayaan yang diberikan dalam mengelola bisnis keluarga.

H1 : Proses suksesi berpengaruh terhadap keberhasilan bisnis keluarga

\section{Pengaruh pemahaman akuntansi} terhadap keberhasilan bisnis keluarga

Sariningtyas dan Diah (2011) menjelaskan manfaat yang didapat dalam pemahaman akuntansi adalah dapat menghindari campur tangan antara uang pribadi dengan uang bisnis, karena kebanyakan bisnis keluarga tidak menerapkan pemahaman akuntansi dengan baik dan mencampurkan uang pribadi dan bisnis. Pencatatan akuntansi sangat membantu sebuah bisnis agar dapat berkembang. Adam (2015) berargumentasi bahwa sebuah bisnis harus dapat membedakan penempatan akun debit kredit dan menghasilkan laporan yang akan dipakai untuk mengambil keputusan, hal ini berpengaruh bagi keberlangsungan bisnis tersebut. Menurut Halim (2013) dalam penelitiannya bahwa pemahaman akuntansi memiliki pengaruh terhadap keberhasilan bisnis keluarga. Dengan adanya pemahaman akuntansi maka dapat memudahkan pemilik bisnis keluarga untuk mengambil keputusan bagi keberlangsungan bisnisnya.

$$
\begin{gathered}
\text { H2 : Pemahaman akuntansi } \\
\text { berpengaruh terhadap } \\
\text { keberhasilan bisnis keluarga }
\end{gathered}
$$

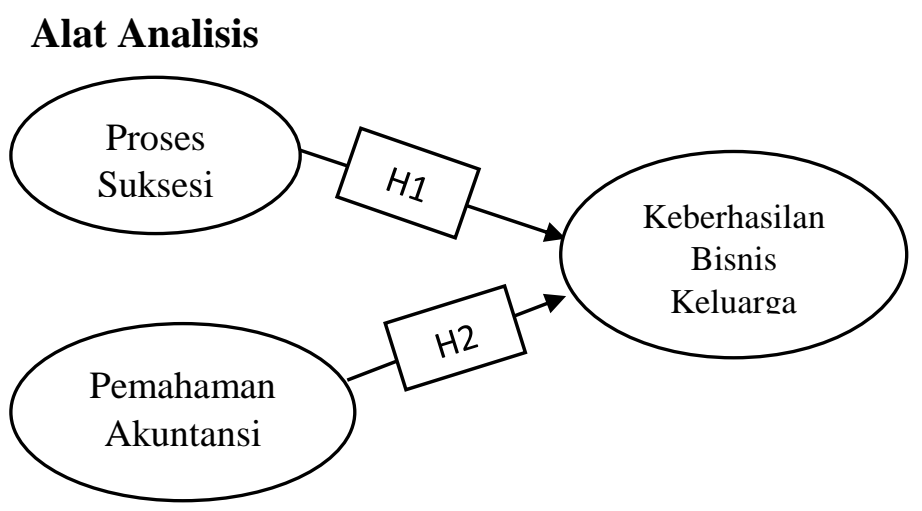

Gambar 2: Kerangka Penelitian

\section{METODE PENELITIAN}

\section{Populasi dan Sampel}

Populasi dalam penelitian ini meliputi bisnis keluarga yang terdapat di Semarang dan Salatiga, Jawa Tengah. Alasan mengapa penelitian ini dilakukan karena Salatiga sebagai jalur penghubung antara Semarang dan Solo. Salatiga bisa disebut sebagai kota kecil dan belum banyak bisnis yang berdiri, namun sekarang Salatiga dikenal sebagai kota industri. Banyak pemilik bisnis yang dapat memanfaatkan peluang dengan memulai bisnis baru nya di Salatiga, dikarenakan Salatiga tidak memiliki tempat wisata. Hal ini yang digunakan sebagai daya tarik 


\section{Nominal: Barometer Riset Akuntansi dan Manajemen}

P-ISSN: 2303-2065 E-ISSN: 2502-5430

Volume 9 No 1 (2019)

pemilik bisnis untuk memulai bisnisnya di Salatiga. Alasan kedua mengapa penelitian ini dilakukan di Semarang yaitu karena banyak bisnis keluarga yang memulai usahanya di Semaranghal ini dapat dikatakan bahwa bisnis keluarga yang berada di Semarang mengalami pertumbuhan bisnis dari tahun ke tahun. Banyak juga bisnis keluarga yang berhasil mendirikan perusahaan besar di Indonesia dan perusahaan tersebut sudah terdaftar dalam Bursa Pasar Modal.

Bisnis keluarga yang ada di Jawa Tengah sejumlah 147.233 berdasarkan data dari Dinkop dan UKM Jateng (2018). Populasi dari penelitian ini sejumlah 1.400 bisnis keluarga yang ada di Kota Semarang dan Kota Salatiga (Aditya 2018). Sampel yang diperoleh sejumlah 158 pengelola bisnis keluarga. Pemilihan sampel ini didasarkan pada purposice sampling dengan kriteria bisnis keluarga sudah berdiri minimal sepuluh (10) tahun, tempat usahanya menetap dan minimal terdapat dua (2) anggota keluarga yang mengelola bisnis dari generasi berbeda. Sebuah bisnis yang telah berdiri lebih dari 10 tahun serta memiliki usaha menetap dan terdapat anggota keluarga yang ikut mengelola bisnis, secara tidak langsung bisnis tersebut sudah menjalankan proses suksesi sejak dini.

\section{Metode Pengumpulan Data}

Penelitian ini memakai pendekatan kuantitatif untuk menguji hipotesis dengan menganalisis apakah suksesi dan pemahaman akuntansi memiliki pengaruh terhadap keberhasilan bisnis keluarga di Semarang dan Salatiga. Data yang digunakan dalam penelitian ini yaitu data primer. Data primer akan diperoleh dengan cara menyebarkan kuisioner kepada responden secara langsung. Penyebaran kuisioner ini dengan cara mendatangi satu persatu calon responden, dan menanyakan kesediaannya untuk mengisi kuisioner.

Pengumpulan data juga dapat dilakukan dengan cara menyebar google form bagi pemilik bisnis keluarga yang memiliki email, dengan mengirimkan link dan menanyakan kesediaannya untuk mengisi kuisioner. Kuisioner akan diukur menggunakan skala ordinal, dengan jarak satu (1) sampai lima (5). Nomor satu (1) diindikasikan sangat tidak setuju, nomor dua (2) diindikasikan tidak setuju, nomor tiga (3) diindikasikan netral, nomor empat (4) diindikasikan setuju dan nomor lima (5) diindikasikan sangat setuju. Model penelitian yang digunakan dalam penelitian ini adalah regresi linier berganda dan kemudian data yang diperoleh akan diolah menggunakan SPPS. 
Tabel 1: Definisi Operasional Variabel

\begin{tabular}{|c|c|c|}
\hline Variabel & Definisi & Indikator \\
\hline $\begin{array}{l}\text { Proses } \\
\text { Suksesi } \\
\text { (Bisnis } \\
\text { Keluarga) }\end{array}$ & $\begin{array}{l}\text { Proses suksesi } \\
\text { adalah proses } \\
\text { dimana pemilik } \\
\text { bisnis atau } \\
\text { pengelola bisnis } \\
\text { akan menyiapkan } \\
\text { calon penerusnya } \\
\text { sejak dini untuk } \\
\text { melanjutkan } \\
\text { memimpin bisnis } \\
\text { yang sudah ada. } \\
\text { Dalam proses } \\
\text { suksesi ini } \\
\text { biasanya } \\
\text { dipengaruhi oleh } \\
\text { beberapa faktor } \\
\text { seperti gender, } \\
\text { keikutsertaan } \\
\text { calon suksesor } \\
\text { dalam mengelola } \\
\text { bisnis sejak dini, } \\
\text { pendidikan, peran } \\
\text { orang tua dalam } \\
\text { mendidik, dan } \\
\text { kepemimpinan } \\
\text { (Halim, 2013; } \\
\text { Wahjono, 2011, } \\
\text { 2009; Wijaya \& } \\
\text { Mustamu, 2014; } \\
\text { Wiratna \& } \\
\text { Tambunan, 2017). }\end{array}$ & $\begin{array}{l}\text { - Keikutser } \\
\text { taan } \\
\text { dalam } \\
\text { mengelol } \\
\text { a bisnis } \\
\text { - Pendidik } \\
\text { an } \\
\text { - Gender } \\
\text { - Peran } \\
\text { Orang } \\
\text { Tua } \\
\text { - Kepemim } \\
\text { pinan } \\
\text { Sumber: } \\
\text { Halim(201 } \\
\text { 3); } \\
\text { (Wahjono } \\
\text { 2011, } \\
\text { 2009); } \\
\text { Wijaya dan } \\
\text { Mustamu(2 } \\
\text { 014); } \\
\text { Wiratna } \\
\text { dan } \\
\text { Tambunan( } \\
\text { 2017). }\end{array}$ \\
\hline $\begin{array}{l}\text { Pemaham } \\
\text { an } \\
\text { Akuntansi }\end{array}$ & $\begin{array}{l}\text { Pemahaman } \\
\text { akuntansi dalam } \\
\text { sebuah bisnis bisa } \\
\text { dilihat dari } \\
\text { pemisahan dana } \\
\text { yang dilakukan } \\
\text { oleh pengelola } \\
\text { atau pemilik bisnis } \\
\text { dalam } \\
\text { menjalankan } \\
\text { aktivitas bisnis } \\
\text { nya, dan dapat } \\
\text { dilihat dari modal } \\
\text { yang dimiliki oleh } \\
\text { pemilik bisnis } \\
\text { berasal dari hutang } \\
\text { atau berasal dari } \\
\text { uang keluarga } \\
\text { (Istiqomah \& } \\
\text { Hatammimi, 2015; }\end{array}$ & $\begin{array}{l}\text { - Pemisaha } \\
\text { n Dana } \\
\text { - Modal } \\
\text { Sumber: } \\
\text { Istiqomah } \\
\text { dan } \\
\text { Hatammim } \\
\text { i(2015; } \\
\text { Septiani } \\
\text { dan } \\
\text { Mustamu(2 } \\
\text { 014). }\end{array}$ \\
\hline
\end{tabular}

\begin{tabular}{llc}
\hline Variabel & Definisi & Indikator \\
\hline & Septiani \& & \\
& Mustamu, 2014). & \\
& & \\
& & \\
\hline Keberhasil & Keberhasilan & $\bullet$ Bisnis \\
an Bisnis & bisnis keluarga & Berkemb \\
Keluarga & dapat diukur dari & ang \\
& kinerja & $\bullet$ Kinerja \\
& keuangannya & Keuanga \\
& setiap periode & n \\
& mengalami & Sumber: \\
& peningkatan atau & Farida \\
& mengalami & dan \\
& penurunan. Selain & Widayant \\
& itu, bisnis tersebut & i(2015); \\
& mengalami & Indriyatni \\
perkembangan & (2013) \\
atau hanya & \\
bertahan di posisi & \\
& awal (Farida \& & \\
Widayanti, 2015; & \\
Indriyatni, 2013). & \\
\hline & & \\
\hline
\end{tabular}

\section{Teknik Analisis Data}

Metode analisis data menggunakan regresi linier berganda. Menurut Janie (2012) untuk menguji pengaruh antara dua atau lebih variabel independen menggunakan regresi linier berganda. Model regresi linier berganda diasumsikan memiliki hubungan linier atau satu garis lurus antara variabel dependen dengan prediktornya. Hubungan ini dapat dijelaskan dengan rumus sebagai berikut.

$$
\mathrm{Y}=\alpha+\beta 1 \mathrm{X} 1+\beta 2 \mathrm{X} 2+\mathrm{e}
$$

Keterangan:

$\mathrm{Y}=$ Variabel dependen

$\alpha=$ Konstanta 
$\beta=$ Koefisien regresi variabel independen $\mathrm{X}=$ Variabel independen

Menurut Janie (2012) terdapat empat (4) uji dalam asumsi klasik diantaranya uji normalitas, uji heteroskedastisitas, uji multikolinieritas dan uji autokorelasi. Keempat uji ini digunakan untuk melihat antara variabel pengganggu memiliki distribusi normal dengan melakukan uji statistik dan analisis grafik, antara model regresi memiliki varian sama (homoskedastisitas) dengan memakai metode statistik dan metode grafik, terdapat korelasi yang tinggi atau sempurna antar variabel independen, serta terdapat korelasi antar residual atau kesalahan pengganggu pada perode $\mathrm{t}$ dengan kesalahan sebelumnya atau pada periode $\mathrm{t}-1$. Uji hipotesis dalam analisis ini menggunakan uji t. Uji t merupakan salah satu uji hipotesis penelitian dalam regresi linier berganda, uji $\mathrm{t}$ bertujuan untuk mengetahui apakah variabel independen (X) secara parsial berpengaruh terhadap variabel dependen $(\mathrm{Y})$.

\section{HASIL DAN PEMBAHASAN}

Pengambilan data ini sudah sesuai dengan sampel yaitu terdapat anggota keluarga yang mengelola bisnis dari generasi yang berberda, tempat usaha yang sudah menetap dan bisnis yang dijalankan sudah 10 tahun. Data yang digunakan dalam penelitian ini memakai data kuantitatif yang datanya diperoleh melalui kuisioner maupun google form. Kuisioner yang disebar sebesar 50, namun hanya 47 yang kembali dan sisanya mengisi melalui google form dengan menyebarkan link penelitian. Sebelum peneliti meminta responden untuk mengisi kuisioner maupun google form peneliti memilih responden yang sesuai dengan kriteria yang ada dengan melakukan wawancara jika responden sudah sesuai dengan kriteria yang ada, peneliti akan menanyakan kesediaan responden untuk mengisi kuisioner ataupun melalui google form.

Berdasarkan data yang telah diperoleh melalui kuisioner maupun google form terkumpul 158 data responden, sebanyak 78 responden Semarang dan 80 responden Salatiga. Dapat diketahui bahwa responden pria lebih banyak daripada wanita, yaitu responden di Semarang sebanyak 43 pria dan 35 wanita sedangkan responden di Salatiga sebanyak 48 pria dan 32 wanita. Berdasarkan pada gambar 1 dapat dijelaskan bahwa terdapat 158 responden dengan pendidikan, gender dan lama usaha yang berbeda beda. Memulai sebuah bisnis sangat diperlukan pendidikan yang baik dalam mengembangkan bisnisnya, memang banyak responden yang mampu bertahan sampai saat. Responden dengan jenis kelamin perempuan yang 


\section{Nominal: Barometer Riset Akuntansi dan Manajemen}

P-ISSN: 2303-2065 E-ISSN: 2502-5430

Volume 9 No 1 (2019)

pendididan akhir SMA/K yang telah menjalankan bisnis keluarga 10 - 15 tahun sebanyak 16 responden, bisnis yang sudah berjalan antara 16 - 20 tahun sebanyak 5 responden dan yang sudah mengelola bisnisnya lebih dari 20 tahun sebanyak 1 responden sedangkan responden dengan jenis kelamin laki - laki yang pendididan akhirnya SMA/K serta telah menjalankan bisnis keluarga 10 - 15 tahun sebanyak 8 responden, bisnis yang sudah berjalan antara 16 - 20 tahun sebanyak 6 responden dan yang sudah mengelola bisnisnya lebih dari 20 tahun sebanyak 2 responden.

Responden dengan jenis kelamin perempuan yang pendididan akhirnya S1 yang telah menjalankan bisnis keluarga 10 - 15 tahun sebanyak 15 responden, bisnis yang sudah berjalan antara 16 - 20 tahun sebanyak 2 responden dan yang sudah mengelola bisnisnya lebih dari 20 tahun sebanyak 1 responden lalu responden dengan jenis kelamin laki -laki yang pendididan akhir S1 yang telah menjalankan bisnis keluarga 10 - 15 tahun sebanyak 21 responden, bisnis yang sudah berjalan antara 16 - 20 tahun sebanyak 7 responden dan yang sudah mengelola bisnisnya lebih dari 20 tahun sebanyak 1 responden. Responden dengan jenis kelamin perempuan yang pendididan akhir S1 Ekonomi yang telah menjalankan bisnis keluarga $10-15$ tahun sebanyak 21

responden, bisnis yang sudah berjalan antara 16-20 tahun sebanyak 5 responden dan yang sudah mengelola bisnisnya lebih dari 20 tahun sebanyak 1 responden sedangkan responden dengan jenis kelamin laki - laki yang pendididan akhir S1 Ekonomi yang telah menjalankan bisnis keluarga 10 - 15 tahun sebanyak 30 responden, bisnis yang sudah berjalan antara 16-20 tahun sebanyak 11 responden dan yang sudah mengelola bisnisnya lebih dari 20 tahun sebanyak 5 responden. Dalam wawancara kepada beberapa responden menganggap bahwa pendidikan sangat penting bagi pengembangan bisnisnya agar tidak dapat dibodohi oleh pihak eksternal, dengan adanya pendidikan maka responden bisa lebih banyak belajar bukan hanya belajar melalui pengalaman saja. Pendidikan juga dapat membantu dalam menjalankan dan membuat keputusan yang akan diambil untuk membuat bisnis semakin berkembang.

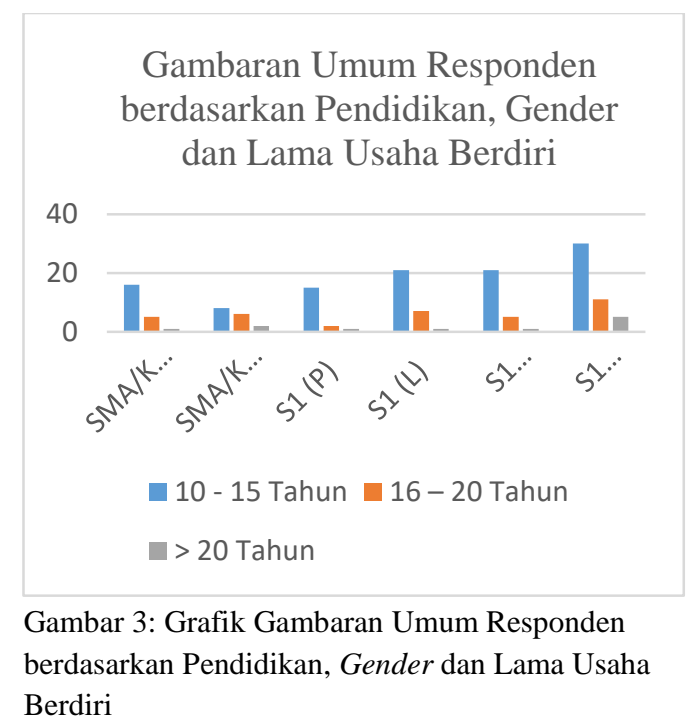


Hasil uji asumsi klasik pada penelitian ini diantaranya uji autokorelasi, uji normalitas, uji multikolinearitas, dan uji heterokedastisitas (terlampir). Hasil uji autokorelasi dapat dilihat bahwa Durbin Watson hitung sebesar 2,126 sedangkan Durbin Watson tabel untuk du sebesar 1,766, dl sebesar 1,714 dan Durbin Watson tabel untuk 4-du sebesar 2,234, 4-dl sebesar 2,286. Sehingga dapat disimpulkan bahwa tidak terjadi masalah autokorelasi dalam penelitian ini. Hasil uji multikolinieritas atas variabel 1 dan variabel 2 menyatakan bahwa tidak terjadi multikolinieritas. Uji normalitas dijelaskan bahwa data mendekati garis lurus, sehingga dapat disimpulkan bahwa data terdistribusi normal. Pada uji normalitas (kolmogorov smirnov) memiliki nilai signifikansi sebesar 0,376 maka dapat disimpulkan bahwa nilai residual berdistribusi normal. Berdasarkan pada hasil uji heteroskedastisitas dapat dilihat bahwa data tidak membentuk suatu alur atau pola tertentu, sehingga dapat disimpulkan tidak terjadi heteroskedastisitas. Pada uji heteroskedastisitas (glejser) dijelaskan bahwa nilai signifikansi untuk Total X1 dan Total X2 sebesar 0,000 maka dapat disimpulkan bahwa tidak terjadi heteroskedastisitas.

Uji t merupakan salah satu uji hipotesis penelitian dalam regresi linier berganda, uji t bertujuan untuk mengetahui apakah variabel independen secara parsial berpengaruh terhadap variabel dependen. Dalam penelitian ini dapat dilihat bahwa nilai signifikansi untuk Total X1 (proses suksesi) sebesar 0,000 sedangkan untuk nilai signifikansi untuk Total X2 (pemahaman akuntansi) sebesar 0,001. Hasil pengujian pada H1 (hipotesis pertama) menunjukan bahwa proses suksesi berpengaruh terhadap keberhasilan bisnis keluarga. Hal ini sejalan dengan penelitian yang telah dilakukanKamener dan Putri; Wiratna dan Tambunan (2017) bahwa proses suksesi berpengaruh terhadap keberhasilan bisnis keluarga. Keberhasilan bisnis keluarga juga disebabkan karena adanya peran orangtua dalam perencanaan suksesi sejak dini serta adanya kepercayaan yang diberikan dalam mengelola bisnis keluarga. Hasil pengujian pada $\mathrm{H} 2$ (hipotesis kedua) menunjukan bahwa pemahaman akuntansi berpengaruh terhadap keberhasilan bisnis keluarga. Hal ini sesuai dengan penelitian yang telah dilakukan Halim (2013) bahwa pemahaman akuntansi memiliki pengaruh terhadap keberhasilan bisnis keluarga. Dengan adanya pemahaman akuntansi maka dapat memudahkan pemilik bisnis keluarga untuk mengambil keputusan bagi keberlangsungan bisnisnya. Berdasarkan hasil penelitian diatas menyatakan bahwa 


\section{Nominal: Barometer Riset Akuntansi dan Manajemen}

P-ISSN: 2303-2065 E-ISSN: 2502-5430

Volume 9 No 1 (2019)

dalam proses suksesi dipengaruhi oleh beberapa faktor, diantara nya pendidikan/ pemahaman mengenai akuntansi dan mengajak calon suksesor untuk ikut terjun dalam bisnis sejak dini.

Pendidikan khususnya pemahaman akuntansi sangat diperlukan dalam dunia bisnis, karena banyak sekali bisnis yang bangkrut disebabkan kurang nya pemahaman mengenai akuntansi. Menurut Devi et al., (2017) pelaporan keuangan memiliki peran penting dalam keberhasilan bisnis keluarga, karena dapat menghasilkan keputusan yang baik jika laporan tesebut dibuat dengan baik dan sesuai dengan standar akuntansi yang berlaku. Pelaporan keuangan yang tidak sesuai dengan standar atau tidak benar dalam membuatnya dapat menghasilkan laporan keuangan yang menyesatkan dan dapat membuat sebuah bisnis dalam bahaya jika pengambilan keputusannya memakai laporan keuangan yang menyesatkan. Gomulia (2013) menjelaskan bahwa bisnis keluarga yang mampu bertahan sampai saat ini, berarti bisnis yang mempunyai formalitas dan profesionalitas dalam menjalankan dan mengelola bisnisnya walaupun dalam pengelolaan bisnisnya dibantu oleh anggota keluarga itu sendiri.

Kegagalan sebuah bisnis bukan hanya disebabkan oleh tidak adanya inovasi dalam menjalankan bisnisnya, persaingan yang ketat, pemahaman akuntansi yang buruk namun perencanaan suksesi sangat mempengaruhi keberhasilan sebuah bisnis. Banyak sekali bisnis yang tidak mampu mempersiapkan calon suksessor dengan baik sejak dini, sehingga menyebabkan beberapa bisnis tidak mampu untuk mengelola bisnis nya sampai ke generasi generasi selanjutnya. Tidak jarang juga bisnis yang mengalami kebangkrutan pada saat generasi ke dua dan seterusnya, hal ini disebabkan bahwa pemimpin sebuah bisnis tidak memperhatikan dengan baik saat mempersiapkan calon suksesor (Kamener \& Putri, 2017). Menurut penelitian Istiqomah dan Hatammimi(2015) tidak memisahkan antara kas pribadi dengan toko merupakan hal sepele, namun jika dibiarkan terus menerus dapat menyebabkan kebangkrutan sebuah bisnis itu sendiri. Penentuan calon suksesor tidak boleh dilakukan dengan terburu buru karena hal ini juga dapat menentukan keberhasilan sebuah bisnis kedepannya. Kamener dan Putri (2017); Halim (2013) juga menjelaskan bahwa proses suksesi dikatakan berhasil jika pemimpin maupun yang menjalankan perusahaan dapat merapakan pemahaman akuntansi dengan baik dalam bisnisnya dan dapat menentukan penerus bisnis yang dapat membuat bisnis menjadi semakin maju dan berkembang. 


\section{KESIMPULAN DAN SARAN}

\section{Simpulan}

Berdasarkan hasil analisis yang telah dijelaskan, dapat dikatakan bahwa proses suksesi dan pemahaman akuntansi berpengaruh terhadap keberhasilan bisnis keluarga. Perencanaan suksesi adalah hal yang sangat penting bagi keberhasilan sebuah bisnis, selain itu peran sebagai pendiri sebuah bisnis juga sangat signifikan dalam memilih calon suksesor yang tepat dan dapat membuat sebuah bisnis menjadi lebih berkembang. Menentukan calon penerus membutuhkan waktu yang sangat lama, karena pendiri harus mempertimbangkan dengan baik agar tidak salah dalam mengambil keputusan. Hal yang diperhatikan bagi pemimpin dalam menentukan calon suksesor adalah memberikan pendidikan formal, pemahaman mengenai berbisnis, mengajak calon suksesor sejak dini untuk ikut terjun langsung dalam mengelola bisnis dan memberikan pemahaman yang baik mengenai berbisnis.

\section{Saran}

Berdasarkan hasil penelitian, saransaran yang dapat diberikan adalah (1) Bagi bisnis keluarga dapat menerapkan pemahaman akuntansi dan menyiapkan calon penerus sejak dini serta memperhatikan pendidikan calon suksesor sejak dini. Hal ini diharapkan dapat menetapkan calon suksesor yang benar dan dapat membuat bisnis yang ada lebih berkembang. (2) Bagi penelitian selanjutnya, diharapkan agar menambahkan variabel lain, seperti latar belakang pendidikan, karakteristik suksesor, komitmen dalam kepemimpinan, serta disarankan untuk menambah ataupun memperluas objek penelitian agar sampel yang dimiliki lebih variatif dan representatif pada keadaan yang sebenarnya.

\section{DAFTAR PUSTAKA}

Adam, H. (2015). Accounting Principle melalui Pendekatan Sistem Informasi. In H. Adam (Ed.), Accounting and Finance (4th ed., pp. 1-110). Bandung: Fakultas Ilmu Komputer dan Sistem Informasi.

Aditya, I. (2018). Salatiga Miliki 1.400 UKM. Retrieved July 17, 2019, from Kamis, 17 Mei 2018 11.32 WIB krjogja.com website: https://krjogja.com/web/news/read/66 490/Salatiga_Miliki_1_400_UKM

Aronoff, C. (2001). Understanding familybusiness survival statistics. Supply House Times, 44(5), 34.

Devi, P. E. S., Herawati, N. T., \& Sulindawati, N. L. G. E. (2017). Pengaruh Tingkat Pendidikan, Pemahaman Akuntansi, dan Ukuran Usaha terhadap Kualitas Laporan Keuangan pada UMKM (Studi Empiris pada UMKM di Kecamatan Buleleng). E-Journal Universitas Pendidikan Ganesha Jurusan, 8, 110. 
Dinas Koperasi dan Usaha Mikro Kota Semarang. (2019). Pertumbuhan UMKM Semarang. Retrieved July 17, 2019 , from https://diskopumkm.semarangkota.go. id/informasi-publik/informasiberkala/umkm

Dinkop dan UKM Jateng. (2018). Data UKM Binaan Provinsi Jawa Tengah Tahun 2008 - 2017. Retrieved July 17, 2019, from 12 November 2018 website:

http://data.jatengprov.go.id/dataset/da ta-ukm-binaan-provinsi-jawa-tengahtahun-2008-2017

Farida, E., \& Widayanti, R. (2015). Analisis Pengaruh Motivasi, Kemampuan Kerja dan Jiwa Wirausaha terhadap Keberhasilan Usaha pada Sentra Kripik Tempe Sanan Malang. Jurnal Akuntansi, Bisnis Dan Manajemen, 22(1), 1-13.

Gomulia, B. (2013). Bisnis Keluarga di Bandung Bagaimana Mereka Bertahan-Berlanjut? 12(2), 125-133.

Halim, Y. (2013). Analisa Suksesi Kepemimpinan pada Perusahaan Keluarga PT. Fajar Artasari di Sidoarjo. Agora, 3(1), 1-15.

Ikatan Akuntan Indonesia. (2016). Standar Akuntansi Keuangan Entitas Mikro, Kecil, dan Menengah (Dewan Standar Akuntansi Keuangan, Ed.). Exposure Draft.

Ikhsan, A., \& Suprasto, H. B. (2008). Teori Akuntansi dan Riset Multiparadigma (1st ed.; Graha Ilmu, Ed.). Yogyakarta: Graha Ilmu.

Indriyatni, L. (2013). Analisis Faktor Faktor yang Berpengaruh Terhadap Keberhasilan Usaha Mikro dan Kecil. Jurnal STIE Semarang, 5(1), 54-70.

Istiqomah, N., \& Hatammimi, J. (2015). Perencanaan Suksesi pada Roti Gempol. E-Proceeding of
Management, 2(3), 2846-2853.

Janie, D. N. A. (2012). Statistik Deskriptif dan Regresi Linier Berganda dengan SPSS (A. Ika, Ed.). Semarang: Semarang University Press.

Kamener, D., \& Putri, D. (2017). Analisis Keberhasilan Suksesi Perusahaan Keluarga di Kota Padang. Industrial Research Workshop and National Seminar Politeknik, 20-26.

Lily, F., \& Praptiningsih, M. (2014). Perancangan Model Suksesi yang Efektif pada Perusahaan Keluarga PT. ABC. Agora, 2(2), 1-10.

Remiasa, M., \& Wijaya, S. A. (2014). Analisis Proses Suksesi Perusahaan Keluarga Studi pada PT Puterasean. Kinerja, 18(2), 141-156. https://doi.org/10.24002/kinerja.v18i2 .526

Rombe, A., Poputra, A. T., \& Kalalo, M. Y. (2016). Analisis Sistem Kas Berbasis Akuntansi Keperilakuan dalam Pelaporan Arus Kas pada PT. Bank Sulutgo. Berkala Ilmiah Efisiensi, 16(01), 459-469.

Sariningtyas, P., \& Diah, T. (2011). Standar Akuntansi Keuangan Entitas tanpa Akuntabilitas Publik pada Usaha Kecil dan Menengah. JAKI, 1(1), 90-101.

Septiani, V., \& Mustamu, R. H. (2014). Perencanaan Suksesi pada Perusahaan Keluarga PT Gading Murni. Agora, 2(2), 1-8.

Stalk, G., \& Foley, H. (2012). Avoid the traps that can destroy family businesses. Harvard Business Review, 90(1-2), 25-27.

Stefanny, M., \& Indriyani, R. (2013). Pengelolaan dan Pengembangan Usaha Furniture pada Aspek Pemasaran CV. Megahtama Cemerlang. Agora, 1(1), 1-10.

Susanto, A. B. (2005). World Class Family 
Business (A. Abdul, Rosyid, Ed.). Jakarta Selatan: Quantum Bisnis \& Manajemen.

Susanto, A., Wijanarko, H., Susanto, P., \& Suwahjuhadi, S. (2007). The Jakarta Consulting Group on Family Business. Jakarta: Publishing Division The Jakarta Consulting Group.

Tjiptono, F. (2013). Kelanggengan Entrepreneurship dalam Bentuk Bisnis Keluarga : Apa yang Telah dan Masih Perlu Diungkap. Entrepreneur Dan Entrepreneurship, 1-12.

Wahjono, S. I. (2011). Gender Problem in Family Business. Balance Economics, Business, Management and Accounting Journal, 14, 55-65.

Wahjono, S. I. U. M. S. (2009). Suksesi dalam Perusahaan Keluarga. Balance, $3,1-15$.

Ward, J. L. (2004). Perpetuating the family business. New York: Palgrave Macmillan.

Wijaya, I., \& Mustamu, R. H. (2014). Analisis Deskriptif Proses Suksesi pada Perusahaan Keluarga yang Bergerak di Bidang Konveyor. Agora, 2(2), 1-7.

Wiratna, D. Y., \& Tambunan, F. (2017). Pengaruh Peran Orangtua sebagai Pendiri Terhadap Keberhasilan Wirausaha di Kelurahan Helvetia Tengah Medan Tahun 2017. AtTawassuth, 2(2), 304-323.

\section{LAMPIRAN}

Uji Multikolinieritas

\begin{tabular}{lllll}
\hline Coefficients $^{\mathbf{a}}$ & & & \\
\hline Model & $\begin{array}{l}\text { Unstand } \\
\text { ardized }\end{array}$ & $\begin{array}{l}\text { Standa } \\
\text { rdized }\end{array}$ & S Collinear \\
& Coeffici & Coeffi & ity \\
ents & cients & & Statistics \\
\end{tabular}

\begin{tabular}{|c|c|c|c|c|c|c|}
\hline & B & $\begin{array}{l}\text { Std. } \\
\text { Erro } \\
\mathrm{r}\end{array}$ & Beta & & $\begin{array}{l}\text { Toler } \\
\text { ance }\end{array}$ & $\begin{array}{l}\text { VI } \\
\text { F }\end{array}$ \\
\hline $\begin{array}{l}\text { (Const } \\
\text { ant) }\end{array}$ & $\begin{array}{l}7, \\
59 \\
8\end{array}$ & $\begin{array}{l}1,98 \\
0\end{array}$ & & $\begin{array}{ll}3, & , 0 \\
83 & 0 \\
6 & 0\end{array}$ & & \\
\hline $\begin{array}{l}\text { TOTA } \\
1 \text { L_X1 }\end{array}$ & $\begin{array}{l}, 2 \\
36\end{array}$ & ,028 & ,553 & $\begin{array}{ll}8, & 0 \\
32 & 0 \\
0 & 0\end{array}$ & ,781 & $\begin{array}{l}1, \\
28 \\
0\end{array}$ \\
\hline $\begin{array}{l}\text { TOTA } \\
\text { L_X2 }\end{array}$ & $\begin{array}{l}, 2 \\
22\end{array}$ & ,067 & 219 & $\begin{array}{ll}3, & , 0 \\
29 & 0 \\
1 & 1\end{array}$ & ,781 & $\begin{array}{l}1, \\
28 \\
0\end{array}$ \\
\hline
\end{tabular}

Uji Normalitas (Kolmogorov Smirnov) One-Sample Kolmogorov-Smirnov Test Unstandardized Residual

\begin{tabular}{|c|c|c|}
\hline $\mathrm{N}$ & & 158 \\
\hline \multirow{3}{*}{$\begin{array}{l}\text { Normal } \\
\text { Parameters }^{\mathrm{a}, \mathrm{b}}\end{array}$} & Mean & $0 \mathrm{E}-7$ \\
\hline & Std. & 2,45748545 \\
\hline & Deviation & \\
\hline \multirow{3}{*}{$\begin{array}{l}\text { Most Extreme } \\
\text { Differences }\end{array}$} & Absolute & ,073 \\
\hline & Positive & 073 \\
\hline & $\overline{\text { Negative }}$ &,- 067 \\
\hline \multicolumn{2}{|c|}{ Kolmogorov-Smirnov Z } & ,912 \\
\hline \multicolumn{2}{|c|}{ Asymp. Sig. (2-tailed) } & ,376 \\
\hline \multicolumn{3}{|c|}{ a. Test distribution is Normal. } \\
\hline
\end{tabular}

Uji Autokorelasi

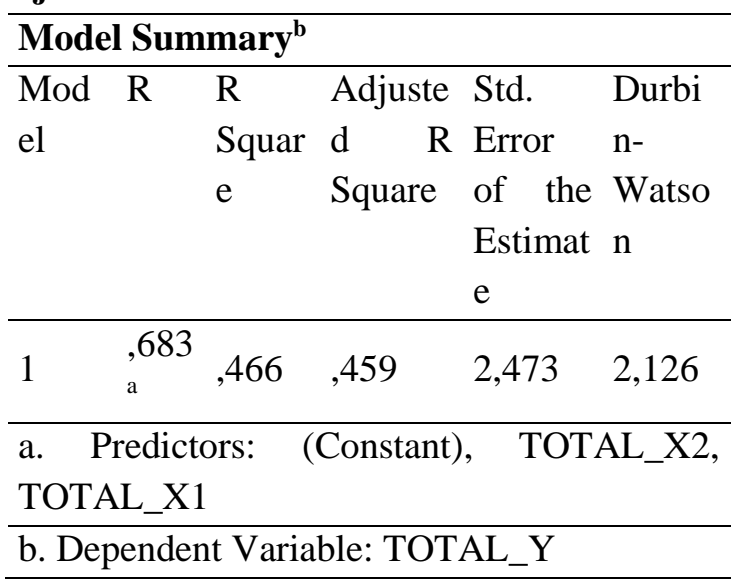




\section{Uji Normalitas}

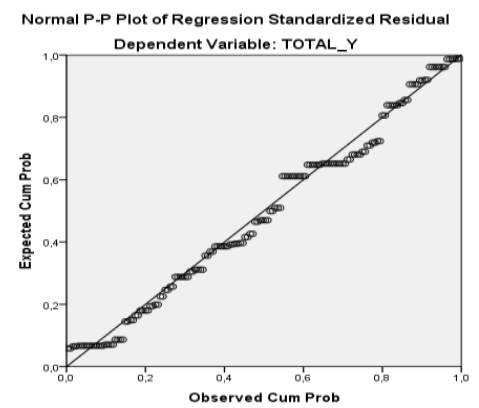

\section{Uji Heteroskedastisitas}

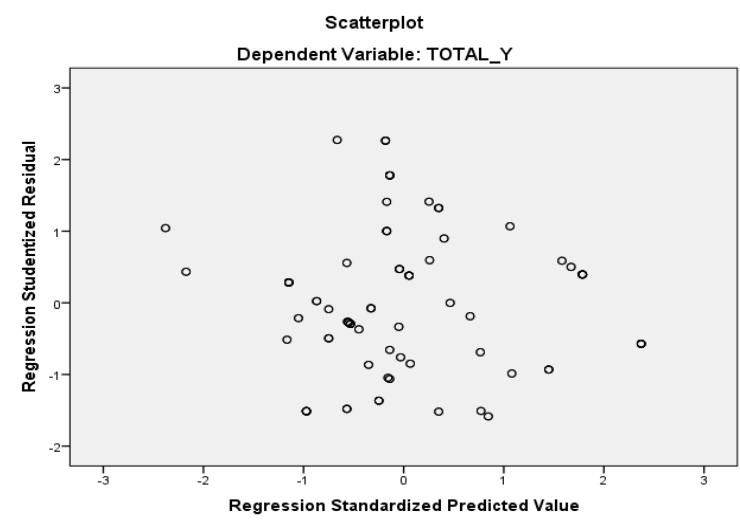

\section{Uji Heteroskedastisitas (Glejser)}

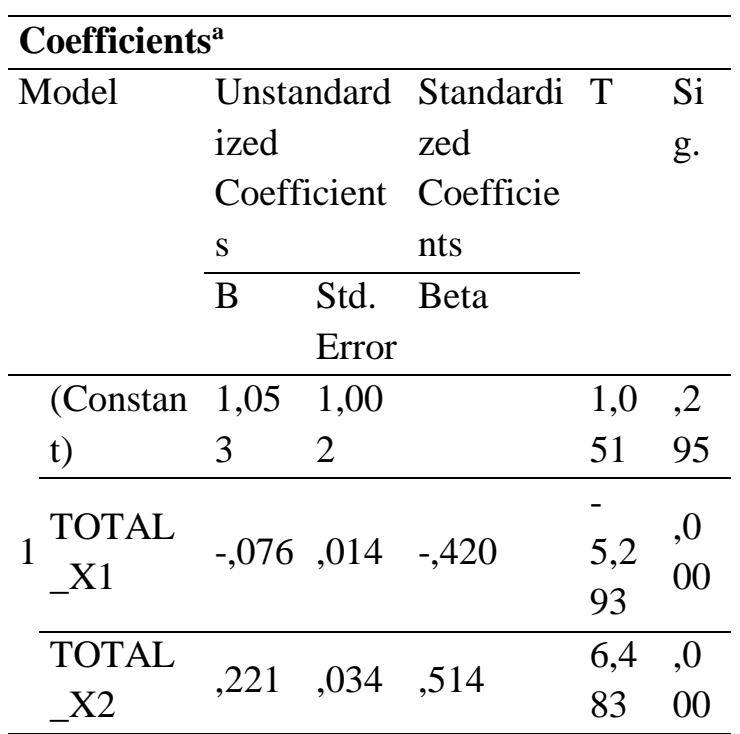

a. Dependent Variable: RES_2
Uji T

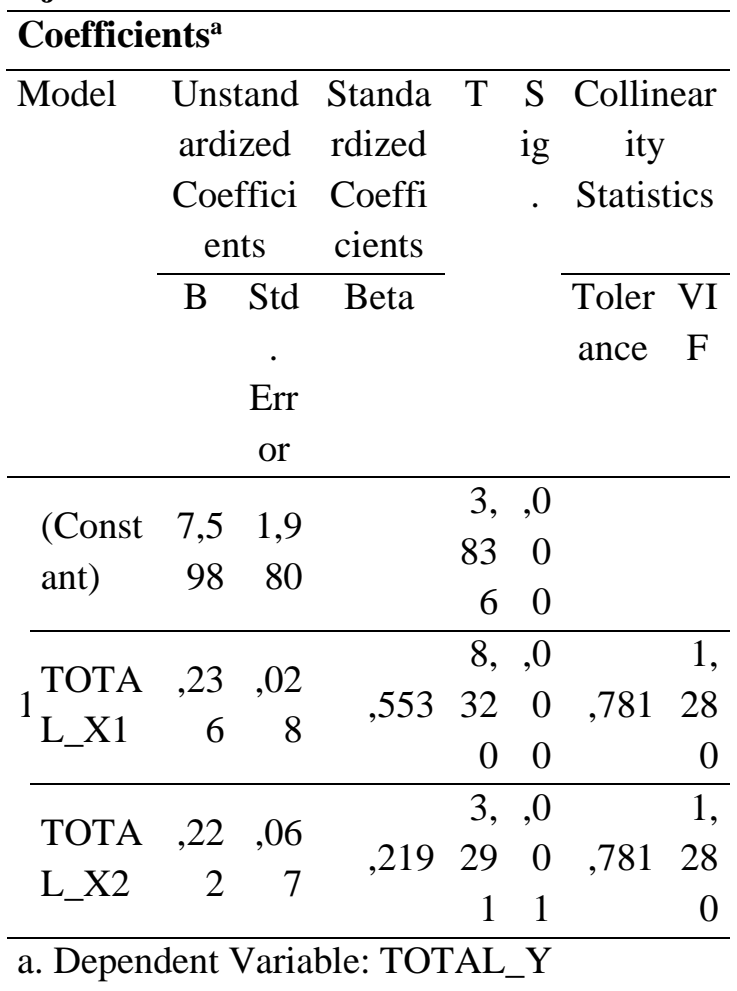

